\title{
Designing and Realization of the Control Networks of the Telecommunication Tower Avala
}

\author{
BRANKO Đ. MILOVANOVIĆ, University of Belgrade, \\ Faculty of Civil Engineering, Belgrade \\ Professional paper \\ UDC: 624.97(497.11) \\ SLAVKO S. VASILJEVIĆ, University of Banja Luka, \\ Faculty of Architecture, Civil Engineering and Geodesy \\ Banja Luka, Bosnia and Herzegovina \\ PETKO R. VRANIĆ, University of Belgrade, \\ Faculty of Civil Engineering, Belgrade
}

\begin{abstract}
The Avala telecommunication tower was destroyed during the NATO bombing in 1999. The construction of the new tower at the same place started in 2007. The new tower consists of reinforced concrete part, with a total height of $142 \mathrm{~m}$, and the antenna part with the height of $70 \mathrm{~m}$. The body shape of the construction is a triangular prism with the equilateral triangle base with sides of $7 \mathrm{~m}$. Civil engineering experts defined structure tolerance of $10 \mathrm{~mm}$ in the horizontal plane and $2 \mathrm{~mm}$ in the vertical plane. The design was produced pursuant to the principles of surveying profession and the conditions set. The paper describes the complexity of designing the control networks for high-rise buildings. The main tasks presented in this article are as follows: choosing the position of the control network points, defining the measuring plan, the network datum and the precision of measurements, calculation of the network quality criteria, and technical conditions for the realization of measurement.
\end{abstract}

Key words: telecommunication tower, control network, precision, reliability

\section{INTRODUCTION}

The first telecommunication Avala tower was built in the period of 1961 - 1965, at the Avala mountain, situated $16 \mathrm{~km}$ south of Belgrade at an altitude of 511 $\mathrm{m}$. The height of the old tower was $202 \mathrm{~m}$ and it was the tallest building in the former Yugoslavia. During the NATO bombing of the SR Yugoslavia, the tower was declared a strategic target and destroyed. The tower was rebuilt during the period of $2006-2009$ as a symbol of Belgrade, on the initiative of the citizens because when arriving in Belgrade, one can see it from almost all routes leading to the city. The new tower was built at where the old one was. The fundamental panels that carried the old structure were used to carry the new one. The entire structure is based on three supports which are arranged at $120^{\circ}$, conceived at a height of 15 $\mathrm{m}$. The body of the tower is prismatic, and the base is

Author's address: Branko Milovanović, University of Belgrade, Faculty of Civil Engineering, Belgrade, Bulevar kralja Aleksandra 73

e-mail: milovano@grf.bg.ac.rs

Paper received: 11.08.2020.

Paper accepted: 24.11.2020. an equilateral triangle with sides of $7 \mathrm{~m}$. It consists of reinforced concrete part and transmission antenna.

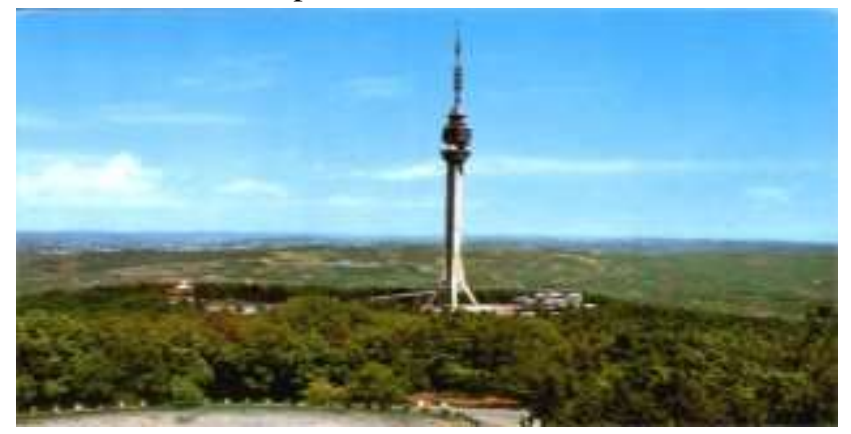

Figure 1 - Avala telecommunication tower

The height of the reinforced concrete section is 142 $\mathrm{m}$, the same as for the destroyed tower. The viewpoint from which we can see the entire Belgrade, most of the Shumadija and Vojvodina is situated at an altitude of $122 \mathrm{~m}$. The antenna has a length of $70 \mathrm{~m}$, which is 10 meters more than the previous one. Figure 1 shows the TV tower.

This high-rise reinforced concrete building has the tolerance in the horizontal plane of $10 \mathrm{~mm}$, and in a vertical plane, the tolerance is $2 \mathrm{~mm}$. Applying the principle of negligibility, the required precision of 
setting out marks is the one-third of a reference network tolerance. All geodetic networks in the engineering geodesy are called control networks. The authors also advocate division to the reference networks, consisting of points around the building at a stable terrain, and a control network consisting of the reference points and points on the object. The purpose of the reference network is to serve as the basis for setting out, and a basis for control of the geometry and the deformation analysis. The quality of the geodetic network is determined by the precision, reliability, sensitivity and the price of realization [1], [5]. It may be noted that the first two criteria jointly ensure the accuracy of our network [3]. The reliability criterion is connected to the possibility of discovering a gross error in measurements (internal), and the influence of an undetected gross error on the parameter assessment (external) [4]. The surveyors have intensively studied the optimization of geodetic networks during the 1980 's. It was carried out by orders [6]. Designing problems can be solved by using analytical or heuristic methods [2]. However, the design of the reference

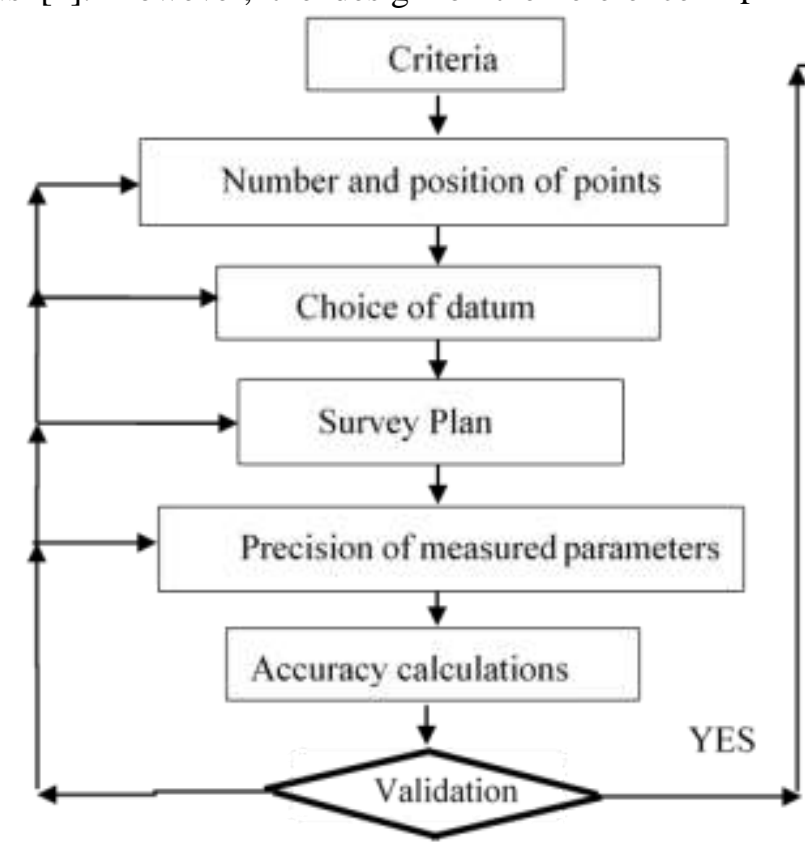

networks in the engineering requires optimization of all orders, using heuristic approach. First, we had defined the criteria the network must meet the requisite of the project task (as defined tolerance) and the principle of the surveying [7], [8]. After network designing accuracy calculation, check if the design criteria are met is performed. When these criteria are met, the technical conditions for the realization of measurements are defined.

This paper presents an algorithm of designing the 1D and 2D reference networks that were applied to this object, network design accuracy and technical conditions for the realization of measurements and criteria of quality.

\section{DESIGNING THE NETWORKS}

In order to complete the project successfully, a certain type of designing algorithm must be used. Figure 2 shows the designing algorithm with all the necessary steps for project designing. These steps are part of the project technical report.

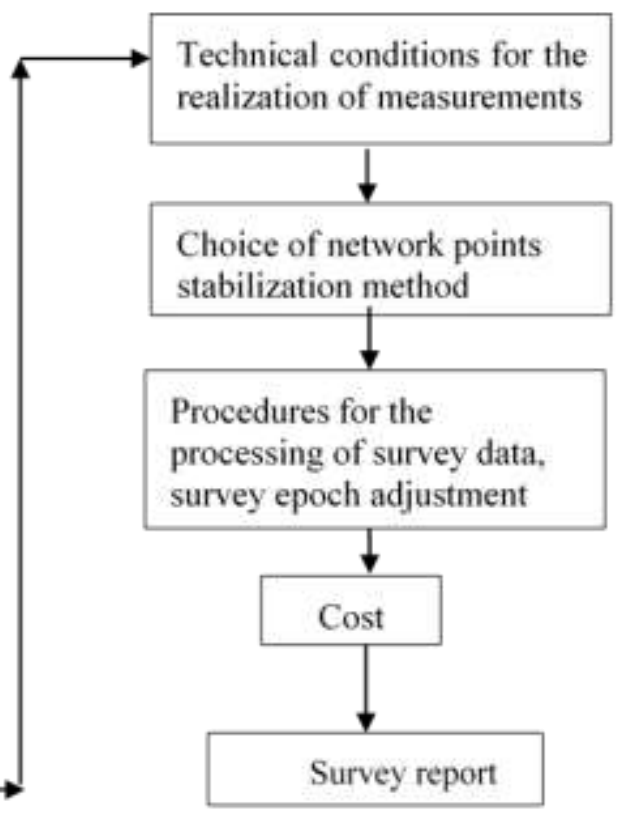

Figure 2 - Control Network Design Algorithm

Engineering networks are separated into horizontal and vertical due to the required precision. Tolerance in the vertical plane is 5-10 times stronger than in the horizontal plane. Civil engineering experts calculated vertical displacements, which will provide the distortions in the horizontal plane ranging from 0.4 to 0.5 of vertical displacement.

\section{$2.12 \mathrm{D}$ Reference network}

Based on the given construction tolerance of 10 $\mathrm{mm}$, the accuracy of setting out the characteristic points of the object and control of derived geometry is
$3 \mathrm{~mm}$, according to the principle of negligibility of errors. Accordingly, the positional accuracy of the points of the reference network may not exceed $1 \mathrm{~mm}$, based on the principle of negligibility. The network is also designed for deformation measurements and the magnitude of structure points movements must be detected „with certainty"1 , which exceed the construction tolerance.

\footnotetext{
1The phrase "be detected with certainty" is used to denote that the power of the test is $0.80 \%$, and the level of significance is 0.05 .
} 
The size of the movements that will be detected for basic structure points is same as tolerance of $10 \mathrm{~mm}$, and $3 \mathrm{~mm}$ for reference points, according to the principle of negligibility. Sketch of the network with the plan of observations is shown in Figure 3.

It was found that there were no previous $2 \mathrm{D}$ reference points existing. The terrain has been filled and reforested since the construction of the first tower. The original idea was to develop a two-ring network around the tower, with the further ring to be used for setting out at the higher altitudes. The network points could not be placed in two rings or at the distance equal to the height of the tower due to the terrain configuration and the fact that area around the tower was stateprotected, thus the lumbering had required a permit. It was decided that the setting out at higher altitudes $\left(\alpha>45^{0}\right)$ would utilize the eyepiece.

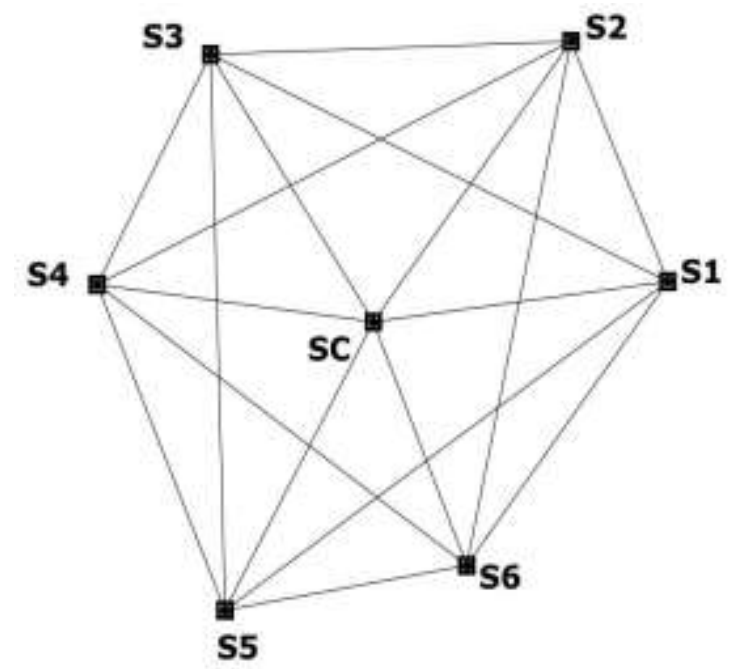

Figure 3 - 2D reference network

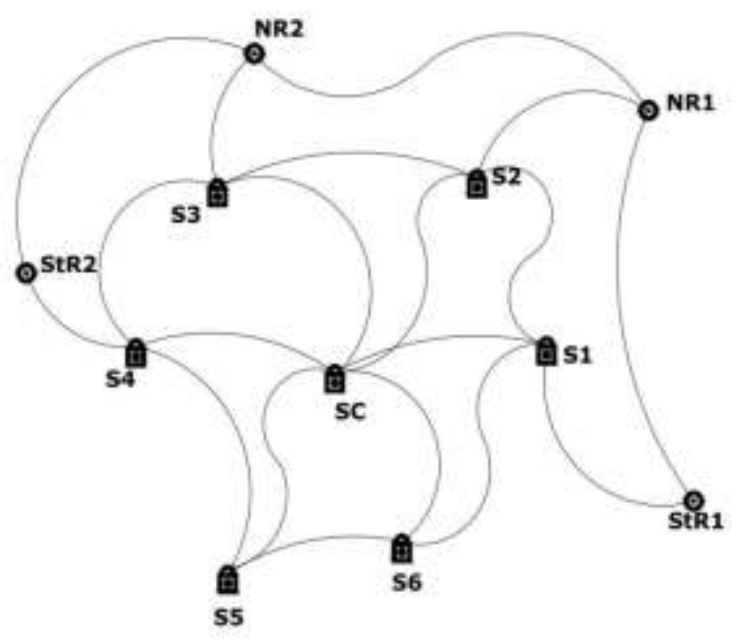

Figure 4 - $1 D$ reference network

Before designing the network, the designer must familiarize with: the characteristics of the structure, characteristics of the terrain, requirements of the building in terms of tolerance, and characteristic points which have to be set out. The designer has to understand the organization of civil works site and technique and dynamics of the construction. The requirements for setting out were to mark console shell with four points. Prism carriers were set on the shell and the height of the segment was defined, with single concrete pouring. Pursuant to the principles of the profession, it was also defined that network should be homogeneous-isotropic. The isotropic network is a network where the ratio between the semi-major axis (A) and the semi-minor axis (B) of the error ellipse does not relation of 2:1 (principle of network consistency). The other criterion refers to reliability, thus the principle of the independent network control will be satisfied. The global measurement of internal reliability of $\bar{r}$ for the $2 \mathrm{D}$ network is $0.3-0.4$, i.e. having at least one redundant measurement towards each point. The third criterion is also related to the network reliability, meaning that the marginal gross error detectable through data-snooping test, may not exceed $5 \sigma_{i}-7 \sigma_{i}\left(\sigma_{i}\right.$ standard deviation of individual measurement). Other criteria of profession are met by initially establishing a reference network (from greater to smaller) and meeting the accuracy requirement which indicates satisfying the tolerance criterion of economy by accuracy.

The central system with 7 points in the network was selected. Each point of the shell can be set out from two stations. The central point of the system is located at the centre of the tower and was supposed to serve for the control of verticality by zenith plumbement. The distance from the central point of the system to peripheral points ranges from 45 to $60 \mathrm{~m}$, and the distance between adjacent external points is approximately $45 \mathrm{~m}$ (S1-S2, S3-S4, S5-S6), S2-S3 60 $\mathrm{m}$ and S4-S5 $66 \mathrm{~m}$.

The coordinate system is local and it is defined during the design plans. The system is defined by the tower centre SC and the bearing from SC to S1. The standard deviation of the arithmetic mean value of measurements does not produce a linear error of the point greater than the required position accuracy of 1 $\mathrm{mm}$. Since the largest distance between the endpoints of the measured values is $115 \mathrm{~m}$, it was obtained that the value of the standard deviation of the arithmetic mean of the measured direction in a number of series is 2", and standard deviation of the arithmetic mean of distances equals the standard deviation of the points' position. The same standard of measuring directions is adopted throughout the network because all points are to be stabilized by pillars, and standard deviation of the direction measurement due to pointing errors is not significant in the network, because all distances are between $45-115 \mathrm{~m}$. For the network design, the datum with minimal trace was adopted, and the defect of the 
network is 3. A number of measured values is $n=62$. According to the design, the direction is measured for all 7 points, and a total number of directions is 34 . It was designed that the distances were measured in both direction and in the adjustment, they are considered independently. These are truly independent measurements, to note. The total number of distances is 28 , and the number of unknown parameters is 21 . The criteria of reliability of the network given on the design accuracy are presented in the Table 1.

Table 1. Criteria of reliability

\begin{tabular}{|l|l|l|}
\hline Criteria of reliability & Local measurement of internal reliability & $\begin{array}{l}\text { Marginal gross error that can be detected } \\
\text { through data-snooping test }\end{array}$ \\
\hline Directions & $0.46-0.69$ & $4 \sigma_{i}$ \\
\hline Distances & $0.81-0.86$ & $7 \sigma_{i}$ \\
\hline
\end{tabular}

$\sigma_{i}$ - standard deviation of measurement

Also, obtained measures of the network precision are shown in the Table 2.

Table 2. Measures of precision

\begin{tabular}{|l|l|l|}
\hline Measure of precision & Min & Max \\
\hline Standard deviation along Y-axis [mm] & 0.2 & 0.7 \\
\hline Standard deviation along X- axis [mm] & 0.2 & 0.6 \\
\hline The standard deviation of point position [mm] & 0.3 & 1.0 \\
\hline The semi-major axis A of the error ellipse[mm] & 0.8 & 1.8 \\
\hline The semi-minor axis B of the error ellipse[mm] & 0.6 & 1.8 \\
\hline A:B & 1.02 & 1.56 \\
\hline $\begin{array}{l}\text { The size of the movement of the reference points, that will be detected "with } \\
\text { certainty" between the two epochs of measurement [mm] }\end{array}$ & 1.0 & 3.2 \\
\hline
\end{tabular}

Technical requirements for the realization of measurement implies the definition of types of instruments according to precision, measurement method, measurement conditions, accuracy conditions, the introduction of weather condition corrections and geometric reductions, monitoring criteria and measurement control, and the crew. Elaborating on the technical terms requires defining the standard deviation of each individual measurement. The following requirements were obtained by calculation: the distances are measured with the precision of $1 \mathrm{~mm}+1 \mathrm{ppm}$ and directions in four double face series with the precision of $1 "$. The monitoring and controlling criteria for the measurement of directions were also obtained as follows:

- the difference allowed for $2 \mathrm{C}$ inside the double face measurement is 10.3";

- the difference allowed between the reduced directions between double face measurements is 10.3",

- the standard deviation of the direction inside the double face measurement is 4";

- the standard deviation of the average direction from four series is 2";

- and for distances:

- the difference allowed of one direction distances, between double face measurements is $3.9 \mathrm{~mm}$;
- the difference allowed between forward and backward measured distances is $4.8 \mathrm{~mm}$.

\subsection{D Reference network}

The project task defines that the size of the displacement that must be ,with certainty“ detected between two epochs of measurement is $d_{p}=1 \mathrm{~mm}$, and that means that the standard deviation of height of the benchmark is $\sigma_{H} \leq \frac{d_{p}}{5}=0.2 \mathrm{~mm}$. The $1 \mathrm{D}$ reference network consists of points of the $2 \mathrm{D}$ reference networks (benchmarks are built into the pillars), two fundamental benchmarks that were used in the construction of the destroyed tower (labeled as StR1 and StR2), and two new fundamental benchmarks (labeled as NR1 and NR2). Sketch of the network with the plan of observations is shown in Figure 4.

The coordinate system is defined by old benchmarks StR1 and StR2. The height differences measurement accuracy at the station was adopted at $0.2 \mathrm{~mm}$. In the calculation of accuracy, the weight of the measured values was calculated as $P_{i}=\frac{1}{n_{i}}, n_{i}$ - number of leveling stations on the leveling line.

The designed number of measured values is $n=19$. The number of unknown parameters is 11 .

The criteria of reliability of the network given on the design accuracy are presented in the Table 3. 
Table 3. Criteria of reliability

\begin{tabular}{|l|c|}
\hline Criteria of reliability & \\
\hline Local measurement of internal reliability & $0.2-0.7$ \\
\hline Marginal gross error that can be detected through data-snooping testing & $1.5 \sigma_{i}$ \\
\hline
\end{tabular}

$\sigma_{i}$ - standard deviation of measurement

Also, obtained measures of the network precision are shown in the Table 4.

Table 4. Measures of precision

\begin{tabular}{|l|l|l|}
\hline Measure of precision & Min & Max \\
\hline The standard deviation by height [mm] & 0.16 & 0.30 \\
\hline $\begin{array}{l}\text { The size of the movement of the referent points, that will be detected „with certainty“ } \\
\text { between the two epochs of measurement [mm] }\end{array}$ & 0.60 & 1.10 \\
\hline
\end{tabular}

\section{REALIZATION OF THE PROJECT DESIGN}

During the project realization, there was a deviation from the design solution in the 2D reference network. For the purposes of the new tower construction, earthworks at the construction site were performed and site organization has changed, thus it was possible to measure many different directions and distances. The contractor had also acquired an instrument with different characteristics relative to the defined features by project solutions.

Measurements in 2D network are carried out using the instrument Leica TCR1201 with direction precision of $1 "$ and distance precision of $2 \mathrm{~mm}+2 \mathrm{ppm}$, and measurements in 1D network were realized using Koni NI007 which precision is $0.7 \frac{\mathrm{mm}}{\sqrt{\mathrm{km}}}$.

Analysis of measurement results had included testing the measurements results for gross errors (which did not exist because the criteria for monitoring and control of measurements were met), test for the presence of systematic errors and assessment of arithmetic mean and its precision. The standard deviation of the mean of reduced directions from four double series is 2.5 ", and the accuracy of the arithmetic mean of distances is 1 $\mathrm{mm}$. Achieved precision of height differences on a single station is $0.28 \mathrm{~mm}$. Testing the hypothesis of the homogeneity of the dispersion had determined this difference to be insignificant.

The number of measured values in a $2 \mathrm{D}$ network was $\mathrm{n}=76,40$ directions and 36 distances. All quality criteria for the network are better than the design solution, clearly due to the much larger number of measured values.

The local measures of internal reliability were between 0.56 and 0.90 , and marginal gross errors that could be detected through data-snooping testing were less than $4 \sigma_{i}$ for both types of measured values. The standard deviations of point position are between 0.28 $\mathrm{mm}-0.37 \mathrm{~mm}$ and error ellipses are nearly circular (the worst ratio $\mathrm{A}: \mathrm{B}$ was 1.17).
In the $1 \mathrm{D}$ reference network, the plan of observations was as defined by the design solution. The quality criteria obtained are almost identical to the design solution.

\section{CONCLUSION}

Designing of geodetic projects is neglected in legal normative documents in Republic of Serbia and this profession is unreasonable put in bad position in comparison to other professions. It should be noted that in the existed legislation, setting out and monitoring of the structure in Serbia are not regulated in appropriate way. There is now clear request of control network project in any legal acts or designing the control network as an indispensable step in monitoring the geometry of structures.

In this paper, it is shown how important is network project design and pre-analysis which is closely related to the future object life and its functionality. Geodesy expert must be familiar with the characteristics and requirements of the building construction, but also with the organization of the construction site in order to satisfy the object requirements. The project designer has a huge responsibility, so it is expected that he should be an expert in engineering surveying area.

\section{ACKNOWLEDGMENT}

This paper is part of the technological development project No TR36009: „The Application of GNSS and LIDAR Technology for Infrastructure Facilities and Terrain Stability Monitoring " funded by the Ministry of Education, Science and Technological Development of the Republic of Serbia

\section{REFERENCES}

[1] Amiri-Simkooei A. R. Comparison of reliability and geometrical strength criteria in geodetic networks. In Journal of Geodesy, 75, pp. 227-233, 2001. 
[2] Amiri-Simkooei A. R. Zengeneh-Nejad F. Asagri J, Zanimpardaz S, Basic Concepts of Optimization and Design of Geodetic Networks, In Journal of Surveying Engineering, pp. 138. 172-183, 2012.

[3] Ašanin S, Pandžić S, Gospavić Z, Milovanović B, Zbirka rešenih zadataka iz inženjerske geodezije, Geokarta, Beograd, 2005.

[4] Baarda W, A testing procedure for use in geodetic networks, Netherland Geodetic Commission, Delft, Netherlands, 1968.

[5] Caspary W. F, Concepts of Networks and Deformation Analysis, Monograph 11, School of Surveying, The University of New South Wales, Kensington, Australia, 1988.

[6] Grafarend, E. W, Sanso F, eds. Optimization and design of geodetic networks, Springer, Berlin, 1985.
[7] Milovanović B, Gospavić Z, Pejović M, Vasiljević S, Projekat osnovne mreže, Kopaonik, Zbornik radova Nacionalnog naučnog skupa - GEO 2014, str. 3-11 (Project of the Core Network, Kopaonik, Proceedings of the National Scientific Conference GEO2014, pp.3-11), 2014.

[8] Milovanović B, Designing the Control Network for Hydrotechnical Objects for the Purpose of Geodetic Monitoring, In International Symposium on Engineering Geodesy SIG 2016 - Proceedings, Croatian Geodetic Society, pp. 71-82, 2016.

[9] Projekat osnovne 2D i 1D mreže TV tornja Avala, Institut za geodeziju i geoinformatiku, Građevinski fakultet Beograd, 2007.

[10]Elaborat o realizaciji projekta osnovne 2D i 1D mreže TV tornja Avala, Institut za geodeziju i geoinformatiku, Građevinski fakultet Beograd, 2007.

\section{REZIME}

\section{PROJEKTOVANJE I REALIZACIJA KONTROLNE MREŽE TELEKOMUNIKACIONOG TORNJA AVALA}

Telekomunikacioni toranj na Avali je uništen tokom NATO bombardovanja 1999. Izgradnja novog tornja na istom mestu, počela je 2007. godine. Novi toranj izgrađen je od armiranog betona, sa ukupnom visinom 142 metra $i$ antenom visine 70 metara. Konstrukcija je oblika trougaone prizme sa jednakostraničnim trouglom u osnovi sa stranicom dužine $7 \mathrm{~m}$. Građevinski stručnjaci definisali su toleranciju konstrukcije od $10 \mathrm{~mm}$ u horizontalnoj ravni i $2 \mathrm{~mm}$ u vertikalnoj ravni. Projektovanje geodetske mreže obavljeno je u skladu sa principima geodetske struke i postavljenim uslovima. U radu je opisana složenost projektovanja kontrolnih mreža za visoke objekte. Glavni zadaci predstavljeni u ovom radu su odabir položaja tačaka kontrolne mreže, definisanje plana opažanja i datuma mreže, preciznost merenja, proračun kriterijuma kvaliteta mreže i tehnički uslovi za realizaciju merenja.

Ključne reči: telekomunikacioni toranj, kontrolna mreža, preciznost, pouzdanost 